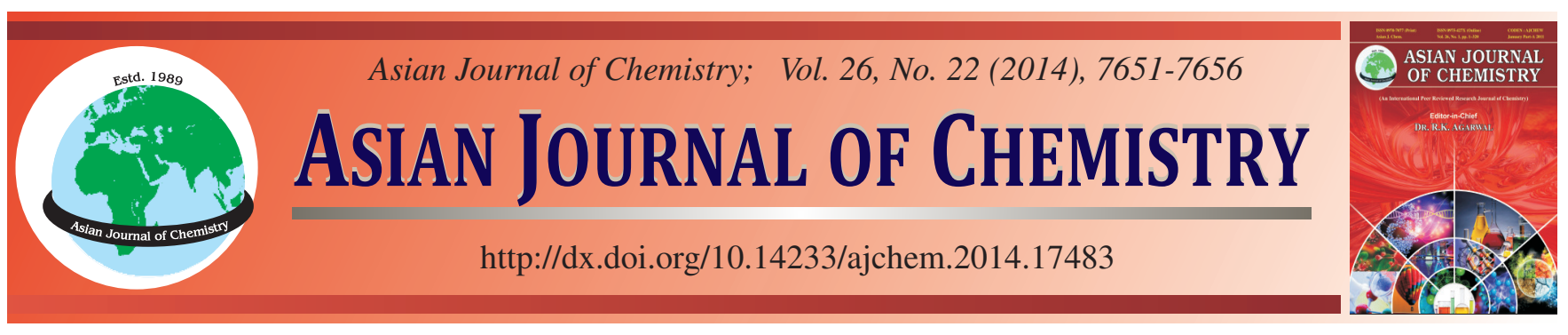

\title{
Analysis of Heavy Metal Contents by Using Poly Aluminum Chloride Water Treatment Residuals and their Implications for Land Application
}

\author{
Ali-Akbar Babael ${ }^{1,2}$, Gholamreza Goudarzi ${ }^{1,2}$, Hassan Dehdari RaD $^{2}$ and Leila Atari ${ }^{2, *}$
}

${ }^{1}$ Environmental Technologies Research Center, Ahvaz Jundishapur University of Medical Sciences, Ahvaz, Iran

${ }^{2}$ Department of Environmental Health, School of Public Health, Ahvaz Jundishapur University of Medical Sciences, Ahvaz, Iran

*Corresponding author: Fax: +98 611 3738282; Tel: +98 611 3738269; E-mail: atari_leila@yahoo.com

Twenty four poly aluminum chloride water treatment residual (PACl-WTR) samples were analyzed for some important heavy metals using ICP-OES apparatus. Results showed that heavy metal contents of poly aluminum chloride water treatment residuals in the wet season were higher than those in the dry season. The order of magnitude in the residual metal concentrations of poly aluminum chloride water treatment residuals was $\mathrm{Al}>\mathrm{Fe}>\mathrm{Mn}>\mathrm{Ni}>\mathrm{Zn}>\mathrm{Ba}>\mathrm{Cu}>\mathrm{Cr}>\mathrm{Pb}>\mathrm{Co}>\mathrm{Sb}>\mathrm{As}>\mathrm{V}>\mathrm{Cd}$. Aluminum concentrations in poly aluminum chloride water treatment residuals were found lower than those levels in the alum sludge of other studies. Moreover, relatively high concentrations of heavy metals and origin of some metal contaminants such as As, Sb and V may be due to the poor quality of the poly aluminum chloride coagulant. According to the results of this study, the poly aluminum chloride water treatment residuals have the potential to be used on land, but for this purpose, considerations must be taken as to the existing background soil characteristics, particularly, the $\mathrm{Cr}$ and $\mathrm{Ni}$ concentrations.

Keywords: Poly aluminum chloride, Water treatment residue, Land application, Seasonal variation, Heavy metals.

\section{INTRODUCTION}

In the process of providing safe drinking water, water treatment plants throughout the world generate residuals as inescapable by-products ${ }^{1,2}$. These residuals are varied depending on raw water sources, treatment operations, process types and the kind and dosage of chemical additives such as coagulants $^{3-5}$. To date, studies have estimated that water treatment plants produce approximately 10000 tons of sludge per day globally, showing that these residuals contain dissolved and suspended forms of organic and inorganic substances, various microorganisms and heavy metals with their potential impacts on human health and the environment ${ }^{6}$. Today, because of stringent environmental regulations regarding the sludge disposal, available options for the disposal of these residuals are increasingly limited. At various areas of the world, landfilling is the most common practice for sludge disposal, but due to the high cost of landfill disposal, application of water treatment residual to agricultural land has been considered as a possible alternative. In this line, land application appears to be a lowcost and desirable option which may not necessarily need regulatory authorizations ${ }^{2,7-9}$.

Since there is a concern that the land application of water treatment residuals will result in soil and water contamination with trace elements which could directly or indirectly be ingested by humans and animals, so to prevent their potential impacts on human health and the environment. The chemical and physical characteristics of the residuals must be specified and compared with national and international sludge regulations before the land applications of the residuals ${ }^{10}$.

Moreover, most water treatment plants in developing countries discharge their residues into surface waters, which are currently recognized as industry-wide pollution problems ${ }^{11}$ containing different degrees of toxicity. These residues would have a toxic load on aquatic organisms and may impair the quality of receiving water if they are left untreated or are discharged directly into receiving water bodies ${ }^{4,7}$.

Heavy metals are found in various emission sources related to industrial and urban activities as well as agricultural practices with adverse environmental effects. Land disposal and land application of municipal and industrial wastes have also contributed to a continuous accumulation of heavy metals in soils ${ }^{12,13}$.

Throughout the world, aluminum coagulants are increasingly used in potable water treatment plants to remove turbidity and dissolved substances ${ }^{14}$, with the wide application today for poly aluminium chloride, which produces huge amounts of PACl-WTRs. Therefore, the objectives of the study were to determine the physiochemical characteristics and the heavy 
metal contents of PACl-WTRs from two water treatment plants (WTP1 and WTP2) and to compare the results with international regulations for the disposal or the land application of sludge.

\section{EXPERIMENTAL}

WTP1 and WTP2, which supply the water requirements of about one million inhabitants of Ahvaz, were monitored. Both plants use conventional treatment process trains and are mainly fed with the Karun river. These plants daily supply about $500,000 \mathrm{~m}^{3}$ of treated water to the city. The treatment trains consist of coagulation by the addition of poly aluminum chloride ( $\mathrm{PACl})$, flocculation, sedimentation, rapid sand filtration with a backwashing period of 8-12 $\mathrm{h}$ and final chlorination. Water treatment residuals resulting from both plants are discharged into the Karun river directly. The location of the water treatment residuals sampling point is shown in Fig. 1.

Sampling: We designed the sampling period to cover both the wet and the dry seasons to take into account the impact of seasonal changes on the PACl-WTRs quality. PACl-WTR samplings were carried out from February, March and April (as the wet season) to July, August and September (as the dry season) in 2011. A total of 24 PACl-WTR samples were collected at the point of PACl-WTRs storage tank of WTP1 and WTP2 (Fig. 1). A core sampler (2 m) was used to collect representative $40 \mathrm{~L}$ samples from both WTPs. Samples were then collected in polyethylene containers previously washed with nitric acid. Next, they were stored in ice-cooled boxes before being transported to the laboratory for immediate analysis.

Analytical methods and instruments: The electrical conductivity (EC) and the $\mathrm{pH}$ were measured using a Hach sensION156 Portable $\mathrm{pH} /$ Conductivity meter. The total, fixed and volatile solids of the WTRs were also measured. Briefly, appropriate volumes of the samples were oven-dried at 103$105^{\circ} \mathrm{C}$, weighed and then ignited in a muffle furnace at $550{ }^{\circ} \mathrm{C}$ for $4 \mathrm{~h}$ before being re-weighed to determine the organic materials loss.

Total metal (Al, As, Ba, Cd, Co, Cr, Cu, Fe, Mn, Ni, Pb, $\mathrm{Sb}, \mathrm{V}$ and $\mathrm{Zn}$ ) concentration was estimated using a hot plate digestion through U.S.EPA method $3050 \mathrm{~B}^{15}$. PACl-WTR samples were dried in an oven at $105^{\circ} \mathrm{C}$ to gain a constant weight and were grounded prior to analysis. Afterwards, $2 \mathrm{~g}$ of the samples were weighed into Erlenmeyer flasks to which $10 \mathrm{ml}$ of $1: 1$ nitric acid was added. The flasks were then covered with watch glasses, being heated on a hot plate without boiling. After $15 \mathrm{~min}$, they were removed from the hot plate, $5 \mathrm{~mL}$ of concentrated nitric acid was added and they were placed back onto the plate for $0.5 \mathrm{~h}$. This procedure was repeated until no brown fume was produced. After being removed from the hot plate, $2 \mathrm{ml}$ of deionized water and $3 \mathrm{~mL}$ of $30 \%$ hydrogen peroxide were added to the flasks. Samples were then filtered through pre-rinsed Whatman 45 filter paper (pore size $1 \mu \mathrm{m}$ ) and diluted to $100 \mathrm{~mL}$. After digestion, the extracts were analyzed by Inductively Coupled Plasma-Optical Emission Spectroscopy (ICP-OES) (Arcos-spectra, Germany). Samples with high concentrations of metal were diluted to fit within the linear region of the calibration curve.

Analyses of the results were performed using the Statistical Package for Social Sciences (SPSS 17). Heavy metals data were tested for normality using the Kolmogorov-Smirnov test. Independent sample T-Test was used to compare means of metal concentrations between the wet and dry seasons.

\section{RESULTS AND DISCUSSION}

Physico-chemical properties of PACl-WTRs: The physiochemical characteristics of PACl-WTRs are shown in Table-1. These characteristics change from season to season, but both PACl-WTRs were similar in some features such as: $\mathrm{pH}$, conductivity and the concentration of total solids. As shown in Table-1, the mean $\mathrm{pH}$ of the PACl-WTRs in the wet and dry seasons is 7.35-7.43 and 7.89-7.95, respectively, which were slightly alkaline. Titshall and Hughes ${ }^{2}$ reported that, in most instances, the WTR samples were neutral to alkaline. The mean EC of PACl-WTRs ranged from $1708 \pm 79.0$ to $2067 \pm 67 \mu \mathrm{S} \mathrm{cm} \mathrm{cm}^{-1}$, which is much higher than the values reported in other studies ${ }^{2,416}$. Differences could result from the raw water quality, water temperature, chemical additives, the season and the treatment processes employed.

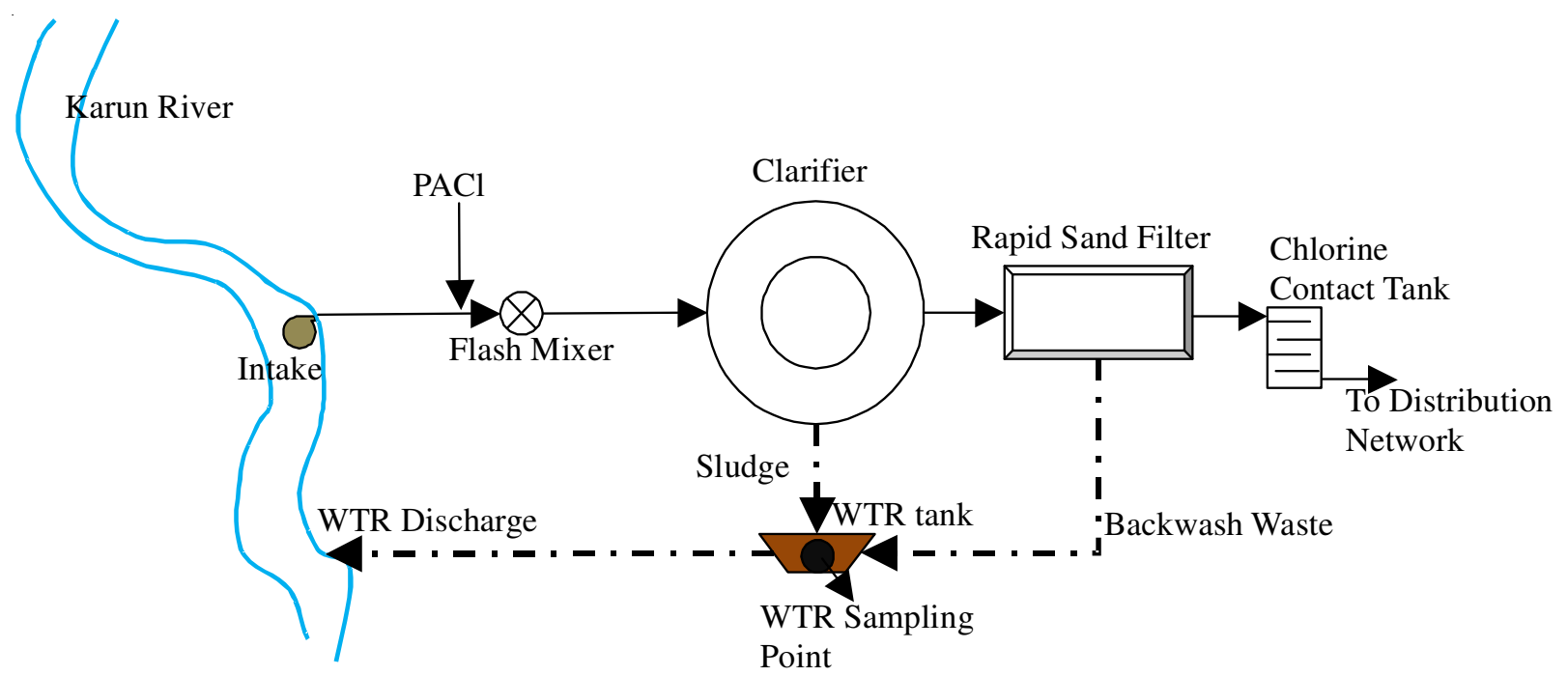

Fig. 1. Location of the water treatment residuals (WTRs) sampling point in the studied water treatment plants (WTPs) 


\begin{tabular}{lcc|cc}
\hline \multicolumn{4}{c}{ TABLE-1 } \\
\multicolumn{1}{c}{ SOME PHYSICO-CHEMICAL PROPERTIES OF THE STUDIED PACl-WTRs } \\
\cline { 2 - 5 } \multicolumn{1}{c}{ Property } & \multicolumn{2}{c}{ PACl-WTR1 } & \multicolumn{2}{c}{ PACl-WTR2 } \\
\cline { 2 - 5 } & Wet season & Dry season & Wet season & Dry season \\
\hline $\mathrm{pH}$ & $7.35 \pm 0.30$ & $7.95 \pm 0.35$ & $7.43 \pm 0.37$ & $7.89 \pm 0.40$ \\
Electrical conductivity $\left(\mu \mathrm{S} \mathrm{cm}^{-1}\right)$ & $1708 \pm 79.0$ & $2048 \pm 81.6$ & $1789 \pm 93.2$ & $2067 \pm 67.0$ \\
Total solids $\left(\mathrm{mg} \mathrm{L}^{-1}\right)$ & $12371 \pm 2309.0$ & $8807 \pm 961.0$ & $11209 \pm 2049.0$ & $8132 \pm 839.0$ \\
Total fixed solids $\left(\mathrm{mg} \mathrm{L}^{-1}\right)$ & $11380 \pm 2137.0$ & $7968.8 \pm 834.4$ & $10313 \pm 1943.0$ & $7359.5 \pm 774.0$ \\
Total volatile solids $\left(\mathrm{mg} \mathrm{L}^{-1}\right)$ & $990.5 \pm 37.0$ & $838.2 \pm 58.6$ & $896.1 \pm 43.2$ & $772.5 \pm 47.0$ \\
\hline
\end{tabular}

Heavy metals content of poly aluminum chloride water treatment residual samples: The poly aluminum chloride water treatment residual samples were analyzed for the total concentration of metals e.g., aluminum (Al), arsenic (As), antimony $(\mathrm{Sb})$, barium $(\mathrm{Ba})$, cadmium $(\mathrm{Cd})$, chromium $(\mathrm{Cr})$, cobalt $(\mathrm{Co})$, copper $(\mathrm{Cu})$, iron $(\mathrm{Fe})$, lead $(\mathrm{Pb})$, manganese $(\mathrm{Mn})$, nickel (Ni), vanadium (V) and zinc ( $\mathrm{Zn}$ ). As shown in Table-2, in both PACl-WTRs, high concentrations of aluminum were found in the wet and dry seasons but these concentrations are lower than the obtained aluminum levels in the alum sludge in other studies (Wet season: $171769 \mathrm{mg} \mathrm{kg}^{-1}$, Dry season: 57730 $\left.\mathrm{mg} \mathrm{kg}^{-1}\right)^{4,8,16-18}$. The concentrations of $\mathrm{Al}$ and $\mathrm{Fe}$ in both residuals were considerably higher than other metal concentrations. In characterizing WTRs, some authors have also found high aluminum and iron concentrations ${ }^{4,8,16,18-21}$. The order of magnitude in the residual metal concentrations in WTP1 and WTP2 was $\mathrm{Al}>\mathrm{Fe}>\mathrm{Mn}>\mathrm{Ni}>\mathrm{Zn}>\mathrm{Ba}>\mathrm{Cu}>\mathrm{Cr}>\mathrm{Pb}>\mathrm{Co}$ $>\mathrm{Sb}>\mathrm{As}>\mathrm{V}>\mathrm{Cd}$. The order is somewhat similar to the results obtained in other studies which are shown in Table-3. These characteristics of PACl-WTRs are influenced by the quality of raw water (data not shown), which, due to the elevated values of colour and turbidity, may require large chemical additions during the water treatment process. Moreover, the rather high-metal concentrations might be related to the low quality of coagulants and other potential contaminants. For example, in the present analyses, it was found that the raw water of WTP1 and WTP2 did not contain detectable levels of As, Sb and V (data not shown). However, they were seen in the PACl sludges. It was concluded that the As, Sb and V might have originated from the coagulant, but this was not experimentally confirmed. It is known that, currently, many contaminant metals in the WTP sludge may result from the additive chemicals such as the coagulant itself ${ }^{22}$.

Table- 3 shows that the heavy metals concentrations of the two PACl-WTRs in this study were similar because both plants use the same raw water source, coagulant agent $(\mathrm{PACl})$ and water treatment operations and processes but these levels are not similar with the results of other studies. Some studies have shown that various parameters of water treatment residuals such as the heavy metals concentrations vary among water treatment plants because of the raw water quality, the treatment process type and its performance, the nature and the source of chemical additives ${ }^{3,4}$.

As shown in Fig. 2, we observed a linear negative and significant correlation between the mean total heavy metal contents and the electrical conductivity (EC) of both PACl-

TABLE-2

HEAVY METALS CONTENT ( $\mathrm{mg} \mathrm{kg}^{-1}$ ) OF THE STUDIED PACl-WTRs (ALL VALUES ARE EXPRESSED ON DRY-WEIGHT BASIS)

\begin{tabular}{|c|c|c|c|c|c|c|c|c|c|c|c|c|c|c|c|}
\hline & & $\mathrm{Al}$ & As & $\mathrm{Ba}$ & $\mathrm{Cd}$ & $\mathrm{Co}$ & $\mathrm{Cr}$ & $\mathrm{Cu}$ & $\mathrm{Fe}$ & $\mathrm{Mn}$ & $\mathrm{Ni}$ & $\mathrm{Pb}$ & $\mathrm{Sb}$ & $\mathrm{V}$ & $\mathrm{Zn}$ \\
\hline \multirow{12}{*}{$\frac{\bar{z}}{3}$} & \multirow{6}{*}{$\begin{array}{l}\tilde{D} \\
\mathbb{J}^{2} \\
\omega^{0} \\
3\end{array}$} & 41079 & 7.14 & 96.8 & 0.23 & 19.8 & 73.4 & 44.6 & 5051 & 496.2 & 102.0 & 27.8 & 9.08 & 2.16 & 69.2 \\
\hline & & 47480 & 7.41 & 99.4 & 2.06 & 21.0 & 75.0 & 45.7 & 5326 & 522.3 & 108.7 & 30.4 & 9.63 & 2.64 & 72.7 \\
\hline & & 41923 & 7.11 & 86.2 & 0.14 & 16.9 & 62.4 & 51.3 & 2105 & 487.0 & 83.4 & 33.2 & 8.83 & 2.06 & 55.1 \\
\hline & & 45440 & 6.51 & 89.2 & 2.03 & 19.6 & 69.8 & 46.3 & 3416 & 522.4 & 97.8 & 19.9 & 9.76 & 2.26 & 65.4 \\
\hline & & 44209 & 6.35 & 109.9 & 1.72 & 22.6 & 73.7 & 48.0 & 4174 & 599.7 & 108.0 & 31.6 & 9.90 & 2.34 & 77.2 \\
\hline & & 46580 & 6.13 & 103.5 & 1.08 & 21.1 & 74.9 & 45.8 & 3562 & 567.6 & 100.3 & 35.0 & 9.37 & 2.70 & 88.2 \\
\hline & \multirow{6}{*}{$\begin{array}{l}\tilde{D} \\
\tilde{J} \\
\text { D } \\
\vec{D} \\
\overrightarrow{0}\end{array}$} & 30898 & 4.51 & 33.8 & 0.49 & 12.9 & 55.0 & 30.1 & 2661 & 489.8 & 52.3 & 3.0 & 5.58 & 0.93 & 42.4 \\
\hline & & 35531 & 3.13 & 38.7 & 0.79 & 8.3 & 57.5 & 35.4 & 2755 & 416.1 & 60.4 & 3.5 & 7.33 & 1.31 & 44.1 \\
\hline & & 40378 & 2.80 & 38.8 & 0.36 & 12.9 & 39.5 & 60.6 & 2360 & 434.0 & 68.9 & 3.9 & 7.63 & 1.67 & 38.8 \\
\hline & & 37140 & 2.57 & 37.0 & 3.32 & 8.9 & 46.0 & 48.9 & 4803 & 356.2 & 67.4 & 8.4 & 6.84 & 1.09 & 42.1 \\
\hline & & 29374 & 3.00 & 41.5 & 0.50 & 7.2 & 75.4 & 44.2 & 4172 & 531.3 & 83.7 & 4.0 & 6.43 & 1.75 & 57.9 \\
\hline & & 38190 & 2.80 & 40.3 & 0.71 & 8.2 & 49.1 & 37.1 & 4758 & 483.3 & 61.9 & 6.2 & 6.35 & 1.34 & 60.8 \\
\hline \multirow{12}{*}{$\frac{\mathfrak{c}}{\xi}$} & \multirow{6}{*}{$\begin{array}{l}\tilde{0} \\
0 \\
0 \\
\infty \\
\tilde{D} \\
3\end{array}$} & 38384 & 6.84 & 91.0 & 1.46 & 18.9 & 69.8 & 41.7 & 4133 & 487.3 & 97.7 & 26.1 & 8.56 & 2.30 & 66.9 \\
\hline & & 46423 & 7.20 & 84.9 & 1.65 & 18.0 & 66.1 & 39.3 & 3789 & 468.3 & 93.6 & 25.0 & 8.56 & 2.38 & 63.7 \\
\hline & & 36472 & 7.19 & 91.6 & 0.60 & 17.1 & 65.4 & 52.5 & 4591 & 507.4 & 87.7 & 36.0 & 8.95 & 2.36 & 60.3 \\
\hline & & 44481 & 6.29 & 89.3 & 0.22 & 21.3 & 73.6 & 49.6 & 5020 & 563.5 & 104.0 & 31.9 & 9.05 & 2.64 & 94.9 \\
\hline & & 38807 & 6.43 & 90.2 & 2.33 & 19.6 & 73.4 & 46.5 & 4949 & 543.1 & 96.4 & 29.0 & 9.16 & 2.43 & 68.3 \\
\hline & & 45865 & 5.75 & 103.5 & 0.28 & 22.1 & 78.9 & 46.4 & 5109 & 595.9 & 106.6 & 26.7 & 9.24 & 2.18 & 76.4 \\
\hline & \multirow{6}{*}{ 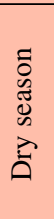 } & 34428 & 2.08 & 32.6 & 1.04 & 10.6 & 47.3 & 27.7 & 2591 & 480.9 & 57.8 & 3.1 & 6.96 & 1.54 & 40.4 \\
\hline & & 31947 & 1.60 & 35.9 & 1.36 & 11.6 & 48.1 & 34.9 & 2501 & 462.4 & 67.2 & 3.0 & 6.73 & 1.83 & 36.3 \\
\hline & & 28614 & 2.04 & 37.9 & 0.41 & 14.4 & 44.4 & 67.1 & 2954 & 406.9 & 68.3 & 6.9 & 6.54 & 2.01 & 44.4 \\
\hline & & 30695 & 3.22 & 34.3 & 2.24 & 13.7 & 54.5 & 56.9 & 2544 & 399.9 & 58.3 & 6.1 & 8.18 & 1.44 & 69.7 \\
\hline & & 29872 & 2.72 & 41.3 & 1.25 & 12.9 & 64.4 & 58.6 & 4838 & 413.0 & 56.1 & 3.2 & 7.73 & 1.40 & 48.9 \\
\hline & & 36442 & 2.97 & 39.8 & 0.36 & 14.2 & 55.1 & 47.4 & 7656 & 414.7 & 72.4 & 3.8 & 7.35 & 1.63 & 50.1 \\
\hline
\end{tabular}




\begin{tabular}{|c|c|c|c|c|c|c|c|c|c|c|c|c|}
\hline \multirow[b]{4}{*}{ Metal } & \multicolumn{12}{|c|}{$\begin{array}{c}\text { TABLE-3 } \\
\text { COMPARISON OF HEAVY METALS CONTENT }\left(\mathrm{mg} \mathrm{kg}^{-1}\right) \text { OF T }\end{array}$} \\
\hline & \multicolumn{4}{|c|}{ Present study } & \multirow{2}{*}{\multicolumn{2}{|c|}{$\begin{array}{c}\text { Ref. } 4 \\
\text { Alum WTRs }\end{array}$}} & \multirow{3}{*}{$\begin{array}{c}\text { Ref. } 20 \\
\text { Alum } \\
\text { WTRs } \\
\text { Total }\end{array}$} & \multirow{3}{*}{$\begin{array}{c}\text { Ref. } 21 \\
\begin{array}{c}\text { Al-based } \\
\text { WTRs }\end{array} \\
\text { Total }\end{array}$} & \multirow{3}{*}{$\begin{array}{c}\text { Ref. 3 } \\
\text { Alum } \\
\text { WTRs } \\
\text { Total }\end{array}$} & \multicolumn{2}{|c|}{ Ref. 8} & \multirow{2}{*}{$\begin{array}{c}\text { Ref. } 18 \\
\text { Alum } \\
\text { WTRs } \\
\end{array}$} \\
\hline & \multicolumn{2}{|c|}{ PACl-WTR 1} & \multicolumn{2}{|c|}{ PACl-WTR 2} & & & & & & $\begin{array}{l}\text { Alum } \\
\text { WTR1 }\end{array}$ & $\begin{array}{l}\text { Alum } \\
\text { WTR2 }\end{array}$ & \\
\hline & $\begin{array}{c}\text { Wet } \\
\text { season }\end{array}$ & $\begin{array}{c}\text { Dry } \\
\text { season }\end{array}$ & $\begin{array}{l}\text { Wet } \\
\text { season }\end{array}$ & $\begin{array}{c}\text { Dry } \\
\text { season }\end{array}$ & $\begin{array}{c}\text { Wet } \\
\text { season }\end{array}$ & $\begin{array}{c}\text { Dry } \\
\text { season }\end{array}$ & & & & & & Total \\
\hline $\mathrm{Al}$ & $\begin{array}{l}44452 \\
(2550)\end{array}$ & $\begin{array}{l}35252 \\
(4291)\end{array}$ & $\begin{array}{l}41739 \\
(4338)\end{array}$ & $\begin{array}{l}32000 \\
(2944)\end{array}$ & 171769 & 57730 & $\begin{array}{l}142020 \\
(26068)\end{array}$ & 42670 & - & 145553 & 127473 & $\begin{array}{l}73816 \\
(3278)\end{array}$ \\
\hline As & $\begin{array}{c}6.78 \\
(0.51)\end{array}$ & $\begin{array}{c}3.14 \\
(0.70)\end{array}$ & $\begin{array}{c}6.62 \\
(0.57)\end{array}$ & $\begin{array}{c}2.44 \\
(0.62)\end{array}$ & - & - & $\begin{array}{l}11.32 \\
(3.53)\end{array}$ & 34 & - & - & - & $\begin{array}{l}73816 \\
(3278)\end{array}$ \\
\hline $\mathrm{Ba}$ & $\begin{array}{l}97.5 \\
(8.9)\end{array}$ & $\begin{array}{l}38.3 \\
(2.7)\end{array}$ & $\begin{array}{l}91.7 \\
(6.2)\end{array}$ & $\begin{array}{l}37.0 \\
(3.3)\end{array}$ & - & - & $\begin{array}{c}84.92 \\
(129.65)\end{array}$ & - & - & - & - & - \\
\hline $\mathrm{Cd}$ & $\begin{array}{c}1.21 \\
(0.87)\end{array}$ & $\begin{array}{c}1.03 \\
(1.13)\end{array}$ & $\begin{array}{c}1.09 \\
(0.85)\end{array}$ & $\begin{array}{c}1.11 \\
(0.69)\end{array}$ & ND & ND & ND & - & 1.6 & - & - & - \\
\hline Co & $\begin{array}{l}20.2 \\
(1.9)\end{array}$ & $\begin{array}{c}9.7 \\
(2.5)\end{array}$ & $\begin{array}{l}19.5 \\
(1.9)\end{array}$ & $\begin{array}{l}12.9 \\
(1.5)\end{array}$ & - & - & - & - & - & - & - & - \\
\hline $\mathrm{Cr}$ & $\begin{array}{l}71.5 \\
(4.8)\end{array}$ & $\begin{array}{c}53.8 \\
(12.4)\end{array}$ & $\begin{array}{l}71.2 \\
(5.1)\end{array}$ & $\begin{array}{l}52.3 \\
(7.3)\end{array}$ & 34.5 & 38.5 & $\begin{array}{l}120.77 \\
(45.43)\end{array}$ & - & 50 & - & - & $\begin{array}{l}81.1 \\
(1.3)\end{array}$ \\
\hline $\mathrm{Cu}$ & $\begin{array}{l}47.0 \\
(2.4)\end{array}$ & $\begin{array}{c}42.7 \\
(11.0)\end{array}$ & $\begin{array}{l}46.0 \\
(4.9)\end{array}$ & $\begin{array}{c}48.7 \\
(15.1)\end{array}$ & 70 & 24 & $\begin{array}{c}31.91 \\
(20.99)\end{array}$ & - & 171 & 153 & 9342 & $\begin{array}{c}141 \\
(3.4)\end{array}$ \\
\hline $\mathrm{Fe}$ & $\begin{array}{c}3939 \\
(1183)\end{array}$ & $\begin{array}{c}3585 \\
(1118)\end{array}$ & $\begin{array}{l}4598 \\
(535)\end{array}$ & $\begin{array}{c}3847 \\
(2068)\end{array}$ & 130500 & 392500 & $\begin{array}{l}10584 \\
(5154)\end{array}$ & 3336 & - & 2434 & 14891 & $\begin{array}{l}3728 \\
(116)\end{array}$ \\
\hline $\mathrm{Mn}$ & $\begin{array}{l}532.5 \\
(43.2)\end{array}$ & $\begin{array}{l}451.8 \\
(62.4)\end{array}$ & $\begin{array}{l}527.6 \\
(48.5)\end{array}$ & $\begin{array}{l}429.6 \\
(33.5)\end{array}$ & 1485 & 1415 & $\begin{array}{c}83.31 \\
(45.48)\end{array}$ & 270 & - & - & - & - \\
\hline $\mathrm{Ni}$ & $\begin{array}{l}100.0 \\
(9.2)\end{array}$ & $\begin{array}{c}65.8 \\
(10.6)\end{array}$ & $\begin{array}{l}97.7 \\
(6.9)\end{array}$ & $\begin{array}{l}63.4 \\
(6.8)\end{array}$ & 50 & 79.5 & $\begin{array}{l}8.30 \\
(3.49)\end{array}$ & - & 44 & - & - & - \\
\hline $\mathrm{Pb}$ & $\begin{array}{l}29.6 \\
(5.4)\end{array}$ & $\begin{array}{c}4.8 \\
(2.1)\end{array}$ & $\begin{array}{l}29.1 \\
(4.2)\end{array}$ & $\begin{array}{c}4.4 \\
(1.7)\end{array}$ & 56 & 75 & $\begin{array}{c}5.71 \\
(3.88)\end{array}$ & 5 & 204 & 6 & 16 & $\begin{array}{l}1.99 \\
(0.4)\end{array}$ \\
\hline $\mathrm{Sb}$ & $\begin{array}{c}9.43 \\
(0.41)\end{array}$ & $\begin{array}{c}6.69 \\
(0.74)\end{array}$ & $\begin{array}{c}8.92 \\
(0.30)\end{array}$ & $\begin{array}{c}7.25 \\
(0.63)\end{array}$ & - & - & - & - & - & - & - & - \\
\hline V & $\begin{array}{c}2.36 \\
(0.26)\end{array}$ & $\begin{array}{c}1.35 \\
(0.32)\end{array}$ & $\begin{array}{c}2.38 \\
(0.16)\end{array}$ & $\begin{array}{c}1.64 \\
(0.24)\end{array}$ & - & - & - & - & - & - & - & - \\
\hline $\mathrm{Zn}$ & $\begin{array}{c}71.3 \\
(11.2)\end{array}$ & $\begin{array}{l}47.7 \\
(9.2)\end{array}$ & $\begin{array}{c}71.8 \\
(12.5)\end{array}$ & $\begin{array}{c}48.3 \\
(11.7)\end{array}$ & 64 & 29 & $\begin{array}{l}19.36 \\
(4.85)\end{array}$ & 30 & 527 & 5 & 51 & $\begin{array}{l}14.37 \\
(1.3)\end{array}$ \\
\hline
\end{tabular}

Note: Standard deviations are shown into parenthesis.

WTRs $\left(\mathrm{r}^{2}=0.877, p\right.$-value $<0.05$ and $\mathrm{r}^{2}=0.828, p$-value $<$ 0.05 for PACl-WTR 1 and PACl-WTR 2, respectively). This indicates that increasing the EC of PACl-WTRs in the dry season leads to a reduction of heavy metals content in the solid phase of PACl-WTRs. Some studies have identified salinity as an effective factor in changing the chemical form and the concentration of heavy metals from the ionic solution phase to the combined phase, the colloidal particles or the sediment $^{23,24}$. Due to high salinity in the dry season as compared with the wet season, metals release from the combined phase into the ionic solution phase.

As shown in Table-4, the concentration of metals in the wet season was higher than the dry season in both PACl-WTRs. T-test results showed that there were a significant differences in metals concentrations between the wet and dry seasons ( $p$-value < 0.05) in PACl-WTRs. The higher concentration of metals observed during the wet season could be attributed to the heavy rainfall and the subsequent river runoff, bringing much industrial and land derived materials along with domestic, municipal and agricultural wastes, which include residues of heavy metals containing pesticides ${ }^{25-29}$. Moreover, as was previously discussed, increasing the electrical conductivity and salinity of WTRs in the dry season results in metals release from the combined phase into the ionic solution phase and subsequently, decreases the concentration of heavy metals in residuals at the dry season more than that in the wet season.

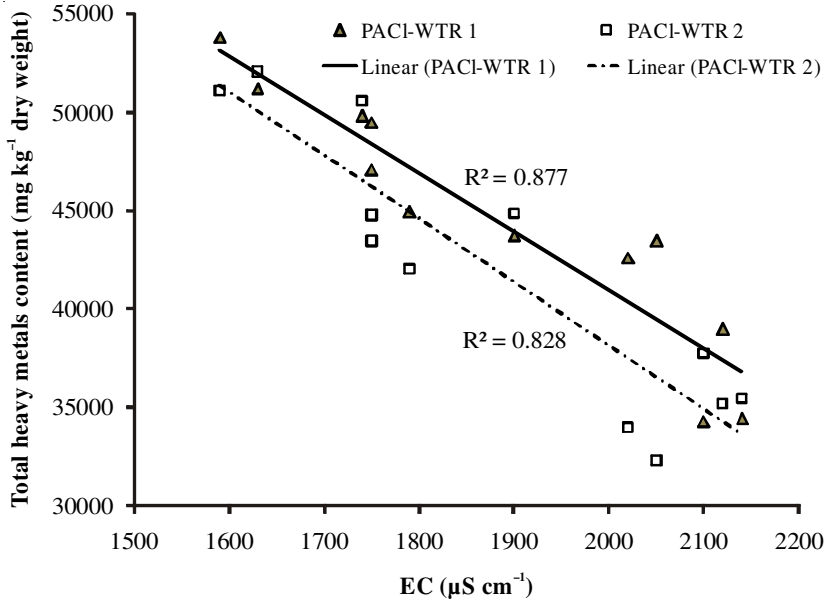

Fig. 2. Correlation analysis of the total heavy metals content and the electrical conductivity of poly aluminum chloride water treatment residual (PACl-WTRs)

Additionally, the rather high-metal concentrations of PAClWTRs in the wet season might be related to the low quality of raw water and other potential contaminants during the wet season, with increased consumption of coagulants and chemical additives during water treatment processes.

As illustrated in Table-4, metal concentrations of PAClWTRs were compared with the EPA standard for land use or the disposal of sludge ${ }^{30}$ and the Canadian soil quality guidelines 
for the protection of environment and human health ${ }^{31}$, illustrating that the concentrations of all the studied metals in both PACl-WTRs were less than the EPA standard for land use or the disposal of WTRs. However, the concentration of chromium in both PACl-WTRs exceeded those of the Canadian guideline for agricultural and residential/parkland application. As for nickel in both PACl-WTRs, the figures exceeded those of the Canadian guideline for total application. Comparisons of chromium and nickel concentrations with the Canadian guideline are shown in Figs. 3 and 4, respectively. There may,

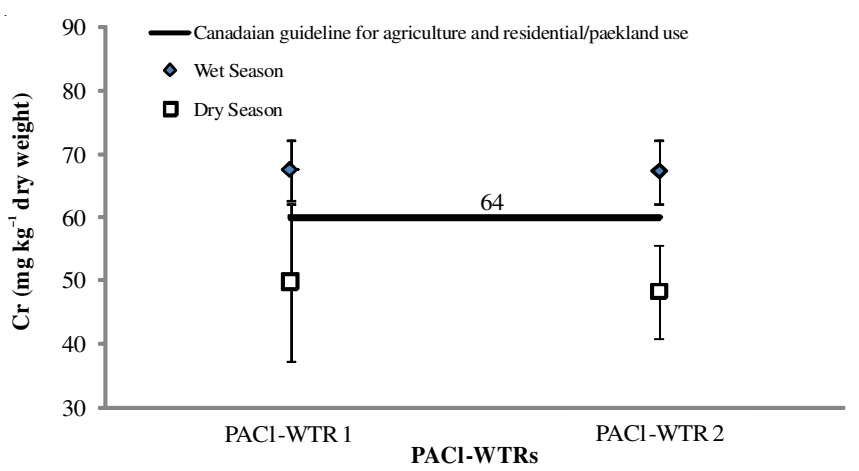

Fig. 3. Comparison of $\mathrm{Cr}$ levels in the two poly aluminum chloride water treatment residuals (PACl-WTRs) with Canadian soil quality guidelines for the protection of environmental and human health

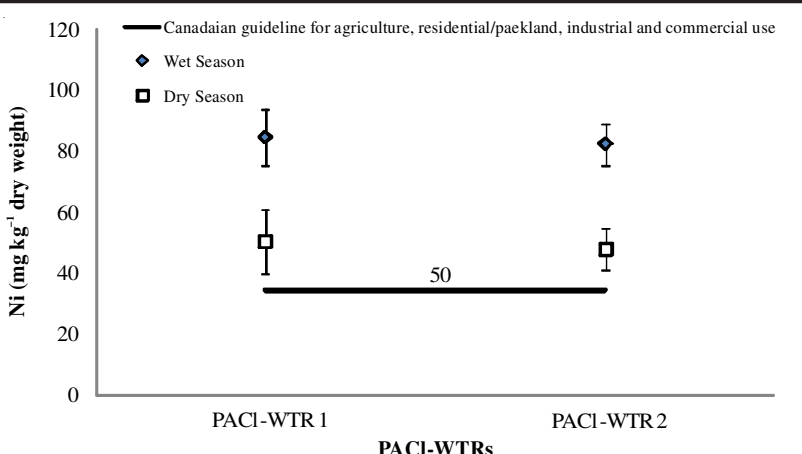

Fig. 4. Comparison of Ni levels in the two poly aluminum chloride water treatment residuals (PACl-WTRs) with Canadian soil quality guidelines for the protection of environmental and human health

however, be a potential risk related to $\mathrm{Ni}$ and most likely also, $\mathrm{Cr}$, if the amended soils were to be acidified. Consequently, if the PACl-WTRs were to be applied to land, attention would also be needed to be given to the acidity of the soil. Furthermore, for land application of PACl-WTRs (as with any other waste), care needs to be given to the existing background soil characteristics.

\section{Conclusions}

Poly aluminum chloride water treatment residuals in two water treatment plants were surveyed with regard to their heavy

\begin{tabular}{|c|c|c|c|c|c|c|c|c|c|}
\hline \multirow[b]{4}{*}{ Metal } & \multicolumn{8}{|c|}{$\begin{array}{c}\text { TABLE-4 } \\
\text { COMPARISON OF PACl-WTRs HEAVY METALS CONTENT }\left(\mathrm{mg} \mathrm{kg}^{-1}\right) \text { OF THE SLUDGE IN } \\
\text { THE WET AND DRY SEASONS AND WITH STANDARDS AND GUIDELINES }\end{array}$} & \\
\hline & \multirow{2}{*}{\multicolumn{2}{|c|}{ PACl-WTR 1}} & \multirow{2}{*}{\multicolumn{2}{|c|}{ PACl-WTR 2}} & \multicolumn{5}{|c|}{ Regulations } \\
\hline & & & & & \multirow{2}{*}{$\begin{array}{c}\text { US EPA part } \\
503^{\mathrm{a}}(1993) \\
\text { [Ref. 30] }\end{array}$} & \multicolumn{4}{|c|}{$\mathrm{CCME}^{\mathrm{b}}$ (2010) [Ref. 31] } \\
\hline & $\begin{array}{c}\text { Wet } \\
\text { season }\end{array}$ & $\begin{array}{c}\text { Dry } \\
\text { season }\end{array}$ & $\begin{array}{c}\text { Wet } \\
\text { season }\end{array}$ & $\begin{array}{c}\text { Dry } \\
\text { season }\end{array}$ & & Agricultural & $\begin{array}{l}\text { Residential/Park } \\
\text { land }\end{array}$ & Industrial & Commercial \\
\hline $\mathrm{Al}^{*}$ & $\begin{array}{l}44452 \\
(2550)\end{array}$ & $\begin{array}{l}35252 \\
(4291)\end{array}$ & $\begin{array}{l}41739 \\
(4338)\end{array}$ & $\begin{array}{l}32000 \\
(2944)\end{array}$ & - & - & - & - & - \\
\hline $\mathrm{As}^{*}$ & $\begin{array}{c}6.78 \\
(0.51)\end{array}$ & $\begin{array}{c}3.14 \\
(0.70)\end{array}$ & $\begin{array}{c}6.62 \\
(0.57)\end{array}$ & $\begin{array}{c}2.44 \\
(0.62)\end{array}$ & 75 & 12 & 12 & 12 & 12 \\
\hline $\mathrm{Ba}^{*}$ & $\begin{array}{l}97.5 \\
(8.9)\end{array}$ & $\begin{array}{l}38.3 \\
(2.7)\end{array}$ & $\begin{array}{l}91.7 \\
(6.2)\end{array}$ & $\begin{array}{l}37.0 \\
(3.3)\end{array}$ & - & 750 & 500 & 2000 & 2000 \\
\hline $\mathrm{Cd}$ & $\begin{array}{c}1.21 \\
(0.87)\end{array}$ & $\begin{array}{c}1.03 \\
(1.13)\end{array}$ & $\begin{array}{c}1.09 \\
(0.85)\end{array}$ & $\begin{array}{c}1.11 \\
(0.69)\end{array}$ & 85 & 1.4 & 10 & 22 & 22 \\
\hline $\mathrm{Co}^{*}$ & $\begin{array}{l}20.2 \\
(1.9)\end{array}$ & $\begin{array}{l}9.7 \\
(2.5)\end{array}$ & $\begin{array}{l}19.5 \\
(1.9)\end{array}$ & $\begin{array}{l}12.9 \\
(1.5)\end{array}$ & - & 40 & 50 & 300 & 300 \\
\hline $\mathrm{Cr}^{*}$ & $\begin{array}{l}71.5 \\
(4.8)\end{array}$ & $\begin{array}{c}53.8 \\
(12.4)\end{array}$ & $\begin{array}{l}71.2 \\
(5.1)\end{array}$ & $\begin{array}{l}52.3 \\
(7.3)\end{array}$ & 3000 & 64 & 64 & 87 & 87 \\
\hline $\mathrm{Cu}$ & $\begin{array}{l}47.0 \\
(2.4)\end{array}$ & $\begin{array}{c}42.7 \\
(11.0)\end{array}$ & $\begin{array}{l}46.0 \\
(4.9)\end{array}$ & $\begin{array}{c}48.7 \\
(15.1)\end{array}$ & 4300 & 63 & 63 & 91 & 91 \\
\hline $\mathrm{Fe}$ & $\begin{array}{c}3939 \\
(1183)\end{array}$ & $\begin{array}{c}3585 \\
(1118)\end{array}$ & $\begin{array}{l}4598 \\
(535)\end{array}$ & $\begin{array}{c}3847 \\
(2068)\end{array}$ & - & - & - & - & - \\
\hline $\mathrm{Mn}$ & $\begin{array}{l}532.5 \\
(43.2)\end{array}$ & $\begin{array}{l}451.8 \\
(62.4)\end{array}$ & $\begin{array}{l}527.6 \\
(48.5)\end{array}$ & $\begin{array}{l}429.6 \\
(33.5)\end{array}$ & - & - & - & - & - \\
\hline $\mathrm{Ni}^{*}$ & $\begin{array}{l}100.0 \\
(9.2)\end{array}$ & $\begin{array}{c}65.8 \\
(10.6)\end{array}$ & $\begin{array}{l}97.7 \\
(6.9)\end{array}$ & $\begin{array}{l}63.4 \\
(6.8)\end{array}$ & 420 & 50 & 50 & 50 & 50 \\
\hline $\mathrm{Pb}^{*}$ & $\begin{array}{l}29.6 \\
(5.4)\end{array}$ & $\begin{array}{l}4.8 \\
(2.1)\end{array}$ & $\begin{array}{l}29.1 \\
(4.2)\end{array}$ & $\begin{array}{c}4.4 \\
(1.7)\end{array}$ & 840 & 70 & 140 & 600 & 260 \\
\hline $\mathrm{Sb}^{*}$ & $\begin{array}{c}9.43 \\
(0.41)\end{array}$ & $\begin{array}{c}6.69 \\
(0.74)\end{array}$ & $\begin{array}{c}8.92 \\
(0.30)\end{array}$ & $\begin{array}{l}7.25 \\
(0.63)\end{array}$ & - & 20 & 20 & 40 & 40 \\
\hline $\mathrm{V}^{*}$ & $\begin{array}{c}2.36 \\
(0.26)\end{array}$ & $\begin{array}{c}1.35 \\
(0.32)\end{array}$ & $\begin{array}{c}2.38 \\
(0.16)\end{array}$ & $\begin{array}{l}1.64 \\
(0.24)\end{array}$ & - & 130 & 130 & 130 & 130 \\
\hline $\mathrm{Zn}^{*}$ & $\begin{array}{c}71.3 \\
(11.2)\end{array}$ & $\begin{array}{l}47.7 \\
(9.2)\end{array}$ & $\begin{array}{c}71.8 \\
(12.5)\end{array}$ & $\begin{array}{c}48.3 \\
(11.7)\end{array}$ & 7500 & 200 & 200 & 360 & 360 \\
\hline
\end{tabular}

${ }^{a}$ EPA standard for use and disposal of sludge, ${ }^{\mathrm{b}}$ Canadian soil quality guidelines for the protection of environmental and human health, "Mean difference is significant at the 0.05 level (between wet and dry season)

Note: Standard deviations are shown into parenthesis 
metals content and the implications for land application. Generally, it seems that the examined PACl-WTRs have the potential for land application. In this line, the following results are obtained:

- Aluminium and iron have predominant concentrations in comparison with other examined metals.

- Heavy metals concentrations at the wet season were higher than those in the dry season due to heavy precipitations in the wet season, higher salinity of PACl-WTRs in the dry season, the low quality of raw water source and the elevated consumption of coagulants during the wet season.

- Aluminum concentrations in PACl-WTRs were found lower than those levels in the alum sludge of other studies. Moreover, relatively high concentrations of heavy metals and origin of some metal contaminants such as As, Sb and V may be due to the poor quality of the PACl coagulant itself.

- In general, according to the results of this study, the PACl-WTRs have the potential for land application from a heavy metals viewpoint. However, if these PACl-WTRs are used on land, considerations need to be taken as to the existing background soil characteristics such as the heavy metals and particularly $\mathrm{Ni}$ and $\mathrm{Cr}$.

In addition, it would be beneficial to examine other parameters of PACl-WTRs from other water treatment plants to improve our understanding on the range of PACl-WTRs produced and their potential for land application.

\section{ACKNOWLEDGEMENTS}

This research was financially supported by the ViceChancellor for Research Affairs at Ahvaz Jundishapur University of Medical Sciences (Grant No. ETRC9005). The authors thank the Vice-Chancellor for Research Affairs of AJUMS.

\section{REFERENCES}

1. J.A. Ippolito, K.A. Barbarick and H.A. Elliott, J. Environ. Qual., 40, 1 (2011)

2. L.W. Titshall and J.C. Hughes, Water SA, 31, 299 (2005).

3. H.A. Elliott, B.A. Dempsey and P.J. Maille, J. Environ. Qual., 19, 330 (1990).

4. R.B. Sotero-Santos, O. Rocha and J. Povinelli, Water Res., 39, 3909 (2005).

5. P. Verlicchi and L. Masotti, in $9^{\text {th }}$ International Conference on the FAO ESCORENA Network on Recycling of Agricultural, Municipal and Industrial Residues in Agriculture, Gargeno, Italy (2001).
6. H.B. Dharmappa, A. Hasia and P. Hagare, Water Sci. Technol., 35, 45 (1997).

7. A.O. Babatunde and Y.Q. Zhao, Crit. Rev. Environ. Sci. Technol., 37, 129 (2007).

8. E. Lombi, D.P. Stevens and M.J. McLaughlin, Environ. Pollut., 158, 2110 (2010).

9. M.L. Silveira, J.L. Driscoll, C.P. Silveira, D.A. Graetz, L.E. Sollenberger and J.M.B. Vendramini, Agron. J., 105, 796 (2013).

10. A.M. Mahdy, E.A. Elkhatib and N.O. Fathi, J. Environ. Sci. Water Resour., 1, 276 (2012).

11. F. Vaezi and F. Batebi, Iran. J. Public Health, 30, 135 (2001).

12. J. Nouri, A.H. Mahvi, G.R. Jahed and A.A. Babaei, Environ. Geol., 55, 1337 (2008).

13. H.B. Shao, Salt Marshes: Ecosystem, Vegetation and Restoration Strategies, NOVA Science Publishers, New York (2012).

14. M. Kimura, Y. Matsui, K. Kondo, T.B. Ishikawa, T. Matsushita and N. Shirasaki, Water Res., 47, 2075 (2013).

15. USEPA (United States Environmental Protection Agency). Method for Acid Digestion of Sediments, Sludges and Soils. Method No. 3050B, Revision 2 (1996).

16. J.A. Ippolito, K.G. Scheckel and K.A. Barbarick, J. Colloid Interf. Sci., 338, 48 (2009).

17. S. Agyin-Birikorang, G.A. O'Connor and T.A. Obreza, Extension Letter SL 299 University of Florida, 8 (2009).

18. A. Hovsepyan and J.C.J. Bonzongo, J. Hazard. Mater., 164, 73 (2009).

19. R.C. Kaggwa, C.I. Mulalelo, P. Denny and T.O. Okurut, Water Res., 35, 795 (2001).

20. T.G. Townsend, Y.C. Jang, P. Jain, and T. Tolaymat, Characterization of Drinking Water Sludges for Beneficial Reuse and Disposal, Florida Center for Solid and Hazardous Waste Management and the Florida Department of Environmental Protection, pp. 1-89 (2001).

21. A.O. Babatunde, Y.Q. Zhao, A.M. Burke, M.A. Morris and J.P. Hanrahan, Environ. Pollut., 157, 2830 (2009).

22. D.A. Cornwell, AWWA J., 92, 78 (2000).

23. K.P. Chen and J.J. Jiao, Environ. Pollut., 151, 576 (2008).

24. B.O. Ekpo and U.J. Ibok, Environ. Geochem. Health, 20, 113 (1998).

25. V. Pragatheeswaran, B. Loganathan, A. Ramesh and V.K. Venugopalan, Mahasagar-Bull. Nat. Inst. Oceanogr., 19, 39 (1986).

26. G. Ananthan, P. Sampathkumar, P. Soundarapandian and L. Kannan, Indian J. Fish., 52, 501 (2005).

27. G. Ananthan, P. Sampathkumar, C. Palpandi and L. Kannan, J. Ecotoxicol. Environ. Monit., 16, 185 (2006)

28. R. Karthikeyan, S. Vijayalakshmi and T. Balasubramanian, J. Microbiol., 2, 50 (2007).

29. R. Sankar, L. Ramkumar, M. Rajkumar, J. Sun and G. Ananthan, J. Environ. Biol., 31, 681 (2010).

30. USEPA (Unitate States Environmental Protection Agency) Part 503 Standards for the Use or Disposal of Sewage Sludge, Fed. Regist., 58, 9387 (1993).

31. CCME (Canadian Council of Ministers of the Environment), Canadian Soil Quality Guidelines for Protection of Environmental and Human Health; Canadian Soil Quality Guidelines; http://ceqg-rcqe.ccme.ca/ (2010). 